\title{
EFFECTIVE PARAMETERS ON THE BEHAVIOR OF CFDST COLUMNS
}

\author{
Ebrahim Farajpourbonab* \\ University of Pune, Institute of Engineering Education and Research, India
}

Concrete Filled Double Skin Steel Tubular (CFDST) columns could be considered as a new type of concrete filled steel tubular (CFT) columns. These columns are composed of two steel tubes in the concentric configurations with concrete between them. In the current study, finite element method was used to analyze the effects of load application, type of material, and geometric parameters of the specimens. It was found that the results obtained from finite element analysis show good agreement with available experimental results. Findings of the current study clearly indicate the high ductility and strength of CFDST columns under axial loading. The results show the significant impact of yield stress of steel section, compressive strength of concrete, thickness and diameter variations on the strength and ductility of CFDST columns.

Key words: CFDST column, Finite element method, Material and geometric parameters, Strength and ductility

\section{INTRODUCTION}

Concrete Filled Double Skin steel Tube (CFDST) columns have been extensively used in the construction of high-rise buildings, factories, and bridges over the past years. A number of investigations have been undertaken to study the strength and behavior of CFDST columns under various types of loading. The results of these studies revealed that an increased ductility and strength can be obtained using double skin tubes owing the "composite action" between steel tubes and sandwiched concrete [01]. According to Han et al (2011) and Li et al (2012), this form of column has higher strength as shown in Figure 1 (uniaxial, flexural, and torsion). The strength to weight ratio is improved significantly by replacement of concrete central part with a hollow steel section. In this case, the confining pressure will be more than CFT column because the inner steel tube would expand outward to increase the confining pressure $[02,03]$.

The results of experimental studies by Han et al (2004) and Tao et al (2004) on slender CFDST columns and CFDST beam-columns showed that the axial capacity of these columns depend on slenderness ratio such that an increase in slenderness ratio causes a decrease in axial capacity of a CFDST column [04,05]. Tao et al (2004) reported that in the experiments a greater gain inductility of the CFDST column and a less local buckling of the inner tube were obtained for sections with smaller Do/to and Di/ti, correspondingly [05]. Uenaka et al (2010) experimentally examined the influence of $X$ on the confinement effect of CFDST columns under concentric axial compression. The tests showed that the confinement effect developed in the CFDST columns improved the concrete strength by $5 \%$ to $30 \%$, which was inversely proportional to $X$ (hollow cross section ratio) [06]. Fan et al (2008) performed a series of tests on CFDST columns subjected to concentric compressive axial load to determine the influence of cross-sectional geometry on their behavior. They found that crosssectional geometry significantly influences the axial behavior of columns. In their tests, circular columns behaved in a ductile way as compared to square columns [07].

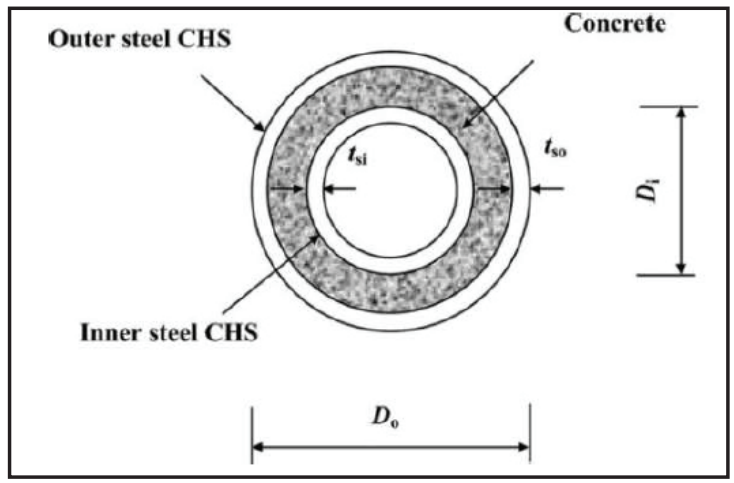

Figure 1: Details and dimensions of CFDST specimen 
Han et al (2010) have developed a nonlinear concrete model for the analysis of CFDST columns to understand the effect of confinement on the strength of the concrete. The confined concrete exhibits much higher strength in comparison with unconfined concrete. This explains why a CFDST column has much strength than the sum of the strengths of outer tube, inner tube, and concrete separately. In addition, the results show that strength and ductility of the concrete in the CFDST column could be controlled by the thickness of the inner and outer tube [08]. Han, Huang, and Zhao (2009) showed that as the slenderness ratio of CFDST columns decreases, or as the nominal steel ratio increases, the stiffness of the curves considerably increases in the elastic stage. Moreover, as the hollowness ratio of CFDST columns increases, stiffness of samples considerably increases in the elastic stage. The stiffness in the descending stage increases as hollowness ratio increases for the area of inner steel increases. It was also found that the ultimate lateral load increases as the nominal steel ratio, strength of outer steel tube or concrete strength increases, or the slenderness ratio decreases [09]. Shah et al (2014) showed that deformation of CFT column is decreasing $10 \%$ to $15 \%$ with the increase in the grade of concrete [10]. Gupta et al (2007) indicated that in circular concentrically loaded CFT samples, with the increase of concrete strength, the confinement effect in the concrete core decreases and strength of the steel tube decreases as the (D/t) ratio increases [11]. According to the past studies, there is a need for numerical study to check the parameters, which affect the ultimate strength. Therefore, in the current study the effects of geometric and material parameters have been investigated on the behavior of CFDST columns under axial loading.

\begin{tabular}{|c|c|c|}
\hline \multicolumn{3}{|c|}{ Nomenclature } \\
\hline$A_{C}$ & Cross section area of concrete & $f_{\text {syi }} \quad$ Yield strength of inner steel tube \\
\hline$A_{S i}$ & Cross section area of inner steel tube & $f_{\text {syo }}$ Yield strength of outer steel tube \\
\hline$A_{\text {So }}$ & Cross section area of outer steel tube & L Length of stub column \\
\hline CFDST & Concrete filled double skin steel tubular & MSI Material specifications of inner steel tube \\
\hline$C F T$ & Concrete filled steel tubular columns & MSO Material specifications of inner steel tube \\
\hline $\mathrm{CHS}$ & Circular hollow section & MCI Material specifications of concrete and inner tube \\
\hline$D_{i}$ & Inside diameter of $\mathrm{CHS}$ & SHS Square hollow section \\
\hline$D_{o}$ & Outside diameter of CHS & $t_{i} \quad$ Inner wall thicknesses \\
\hline$E_{c}$ & Concrete modulus of elasticity & $t_{o} \quad$ Outer wall thicknesses \\
\hline $\begin{array}{l}E_{s} \\
f_{c}^{\prime} \quad M\end{array}$ & $\begin{array}{l}\text { Steel modulus of elasticity } \\
\text { Iaximum compressive strength of concrete }\end{array}$ & $\chi \quad$ Hollow cross section ratio, given by ${ }^{D_{i}} /\left(D_{O}-2 t_{S O}\right)$ \\
\hline
\end{tabular}

\section{FINITE ELEMENT MODELING OF CFDST COLUMNS}

In order to understand the structural behavior of CFDST columns and carry out comparative investigation under axial loading, material and geometric nonlinear finite element analysis have been undertaken. The models were simulated using ANSYS R 10.0 (2005) finite element software designed especially for advanced structural analysis [12].

\section{CHARACTERISTICS OF MODELS}

ANSYS R 10.0 (2005) elements and capabilities are as follows [12].
SOLID65 (for the modeling of concrete) is used for the modeling of concrete, with or without reinforcing bars. It is capable of cracking model in tension and crushing model in compression. The major property of this element is the treatment of nonlinear material properties. Concrete is capable of cracking (in 3 orthogonal directions), crushing, plastic deformation, and creep. SOLID45 (for the modeling of steel wall and steel tube) is used for the modeling of steel walls. The element has plasticity, swelling, stress stiffening, creep, large strain, and large deflection capabilities. CONTAC52 (for the modeling of gap between steel and concrete) represents two surfaces that might maintain or break physi- 
cal contact or might slide relative to each other. The element is capable to support compression members in the normal direction to the surfaces and Coulomb shear friction in the tangential direction.

\section{MATERIAL CHARACTERISTIC}

The stress-strain behavior of the steel wall and in-filled concrete, used for geometric and materi-

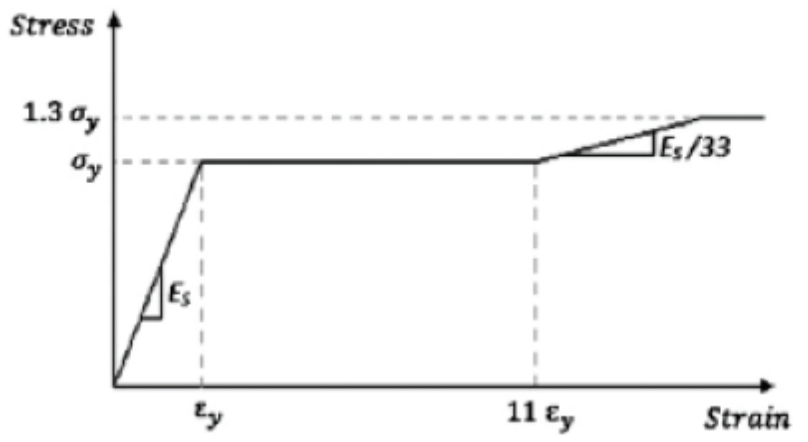

Figure 2: tress-strain of steel material

For the concrete element, the elastic modules (Ex), the Poisson's ratio $\left(V_{x y}\right)$, the values for the ultimate tensile strength $\left(f_{r}\right)$ and ultimate compressive strength $\left(f_{c}\right)$ are the properties of isotropic material as shown in Figure 3.

\section{ANSYS ANALYSIS AND VALIDATION}

The accuracy and feasibility of the numerical results was verified by the comparing the calculated results with the experimental observations of Tao et al (2004) under axial loading [05]. al static analyses according to Schneider (1998) and Mursi (2003), is given in Figures 2 and 3, respectively $[13,14]$. Considering Figure 2, the behavior of steel is characterized with an initial linear elastic segment of stress-strain relationship with a elastic modulus of $200 \mathrm{GPa}$ and up to the yield stress $f_{y}\left(\mathrm{ST} 37\right.$ with $\left.\mathrm{Fu}=370 \mathrm{~N} / \mathrm{mm}^{2}\right)$, which is equal to $280 \mathrm{MPa}$, followed by a strain plateau of varying length and a following region of strain hardening.

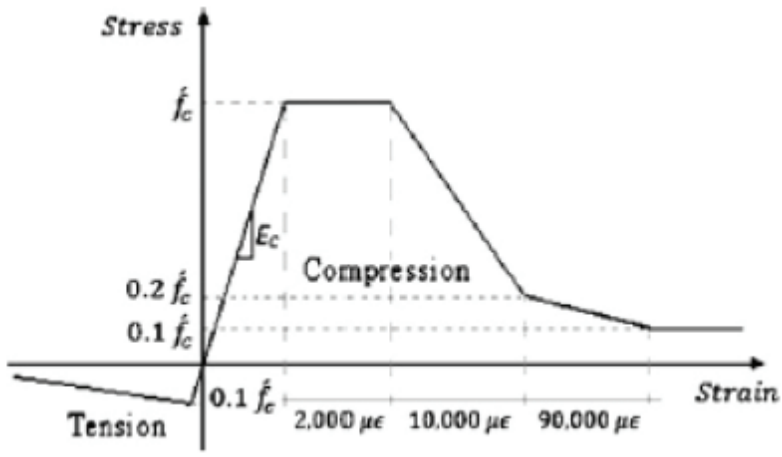

Figure 3: Stress-strain of concrete material

The specifications of circular section (cc2a) of CFDST column used in experimental investigation are presented in Table 1. Figure 4 shows the experimental and numerical load- displacement response of a CFDST sample under axial loading. It is found that the columns behavior predicted by the finite element analysis closely followed the behavior shown by the experimental results. Consequently, it was observed that the finite element method has a sufficient degree of reliability to be implemented in undertaking nonlinear analyses of CFDST columns.

Table 1. The specifications of the experimental CFDST columns (after Tao et al)

\begin{tabular}{|c|c|c|c|c|c|c|c|c|c|}
\hline \multicolumn{3}{|c|}{ Steel Properties } & \multicolumn{2}{|c|}{$\begin{array}{c}\text { Concrete } \\
\text { Properties }\end{array}$} & \multirow[b]{2}{*}{$x$} & \multirow[b]{2}{*}{$\frac{\mathrm{L}}{(\mathrm{mm})}$} & \multirow[b]{2}{*}{$\mathrm{D}_{\mathrm{i}} \times \mathrm{T}_{\mathrm{si}}$} & \multirow[b]{2}{*}{$\mathrm{D}_{0} \mathrm{xt}_{\mathrm{s} 0}$} & \multirow[b]{2}{*}{ Specimen } \\
\hline $\begin{array}{c}\mathrm{E}_{\mathrm{s}} \\
(\mathrm{MPa})\end{array}$ & $\begin{array}{c}\mathrm{f}_{\text {syi }} \\
(\mathrm{MPa})\end{array}$ & $\begin{array}{c}f_{\text {syo }} \\
(\mathrm{MPa})\end{array}$ & $\begin{array}{c}\mathrm{E}_{\mathrm{c}} \\
(\mathrm{MPa})\end{array}$ & $\begin{array}{c}f_{c}^{\prime} \\
(\mathrm{MPa})\end{array}$ & & & & & \\
\hline 200000 & 396.1 & 275.9 & 33300 & 47.4 & 0.47 & 540 & $48 \times 3$ & $180 \times 3$ & $\mathrm{cc} 2 \mathrm{a}$ \\
\hline
\end{tabular}

\section{NUMERICAL INVESTIGATIONS}

For investigation of the effective parameters on the behavior of CFDST columns as shown in Figure 1, various concrete strengths and steel stresses have been considered for the analyses as follows:

A) Material specifications

i. Effect of various yield stresses of steel on the behavior of CFDST columns.

ii. Effect of various compressive strengths of concrete on the behavior of CFDST columns.

B) Geometric specifications (slenderness and compactness of steel section)

i. Effect of thickness variations of steel wall on the behavior of CFDST columns. 
ii. Effect of diameter variations of steel wall on the behavior of CFDST columns. iii. Effect of load application type on the behavior of CFDST columns.

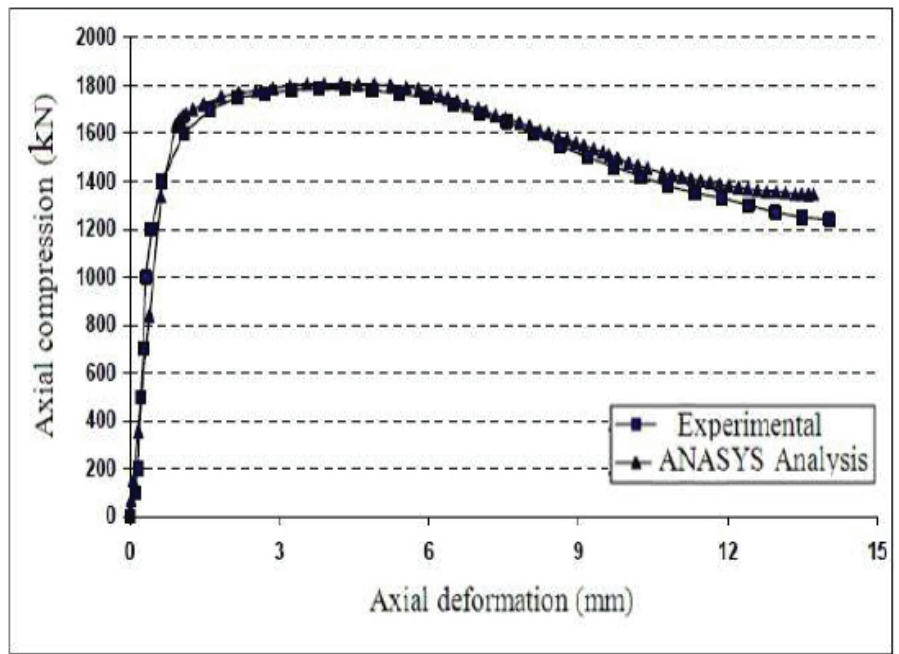

Figure 4: Experimental and numerical responses of a CFDST column (cc2a Specimen)

The following are assumptions that have been taken into considerations for the selection of these sections:

1. CFDST columns have been selected with typical dimensions having a high load bearing capacity ( $\mathrm{L}=3000 \mathrm{~mm}$ )

2. Steel wall thickness has been selected according to ACl and AISC codes [15, 16], so that the local buckling may not be observed at lower loads.

3. The columns are considered as fixed-end columns

4. Before loading, enough imperfection is applied towards the buckling directions.

\section{EFFECT OF VARIOUS YIELD STRESSES OF STEEL}

In order to assess the yield stress effects of steel wall, two states have been considered as fol- lows:

1. First, yield stress of inner steel wall has a fixed amount (320 MPa), and the yield stress of outer steel wall is variable as specified in Table 2

2. Second, yield stress of outer steel wall has a fixed amount (320 MPa), and the yield stress of inner steel wall is variable as specified in Table 3.

For example, MSO400 is the sample, which the yield stress in outer steel wall is variable, supposing that the yield stress of inner steel wall is constant (320 MPa). In addition, MSI280 is the sample which the yield stress in inner steel wall is variable, supposing that the yield stress of outer steel wall is constant (320 MPa).

Table 2: The material specifications of specimens (Variations of $f_{\text {syy }}$ )

\begin{tabular}{|c|c|c|c|c|c||c||}
\hline \multicolumn{3}{|c|}{ Steel properties } & \multicolumn{2}{c||}{ Concrete properties } & \multirow{2}{*|}{} \\
\cline { 1 - 4 } $\begin{array}{c}\mathrm{E}_{\mathrm{s}} \\
(\mathrm{MPa})\end{array}$ & $\begin{array}{c}\mathrm{f}_{\text {syi }} \\
(\mathrm{MPa})\end{array}$ & $\begin{array}{c}\mathrm{f}_{\text {syo }} \\
(\mathrm{MPa})\end{array}$ & $\begin{array}{c}\mathrm{E}_{\mathrm{c}} \\
(\mathrm{MPa})\end{array}$ & $\begin{array}{c}\mathrm{f}_{\mathrm{c}}{ }_{\mathrm{c}} \\
(\mathrm{MPa})\end{array}$ & $\mathrm{x}$ & Specimen \\
\hline 200,000 & 320 & 240 & 35400 & 50 & 0.495 & MSO 240 \\
\hline 200,000 & 320 & 280 & 35400 & 50 & 0.495 & MSO 280 \\
\hline 200,000 & 320 & 320 & 35400 & 50 & 0.495 & MSO 320 \\
\hline 200,000 & 320 & 360 & 35400 & 50 & 0.495 & MSO 360 \\
\hline 200,000 & 320 & 400 & 35400 & 50 & 0.495 & MSO 400 \\
\hline
\end{tabular}

Figure 5 shows load-yield stress of steel corresponding response of MSI and MSO samples. It can be seen that load carrying capacity and post yield behavior of MSI280, MSO360, and
MSO400 samples are significantly higher than that of MSO280, MSI360, and MSI400 samples, respectively. 
Table 3: The material specifications of specimens (Variations of $f_{\text {syj }}$ )

\begin{tabular}{|c|c|c|c|c|c||c||}
\hline \multicolumn{3}{|c|}{ Steel properties } & \multicolumn{2}{c|}{ Concrete properties } & \multirow{2}{*}{ S } & Specimen \\
\hline $\begin{array}{c}\mathrm{E}_{\mathrm{s}} \\
(\mathrm{MPa})\end{array}$ & $\begin{array}{c}\mathrm{f}_{\text {syi }} \\
(\mathrm{MPa})\end{array}$ & $\begin{array}{c}\mathrm{f}_{\text {syo }} \\
(\mathrm{MPa})\end{array}$ & $\begin{array}{c}\mathrm{E}_{\mathrm{c}} \\
(\mathrm{MPa})\end{array}$ & $\begin{array}{c}\mathrm{f}_{\mathrm{c}}{ }^{\prime} \\
(\mathrm{MPa})\end{array}$ & & \\
\hline 200,000 & 240 & 320 & 35400 & 50 & 0.495 & MSI 240 \\
\hline 200,000 & 280 & 320 & 35400 & 50 & 0.495 & MSI 280 \\
\hline 200,000 & 320 & 320 & 35400 & 50 & 0.495 & MSI 320 \\
\hline 200,000 & 360 & 320 & 35400 & 50 & 0.495 & MSI 360 \\
\hline 200,000 & 400 & 320 & 35400 & 50 & 0.495 & MSI 400 \\
\hline
\end{tabular}

Considering Figures 5 and 6, it was defined that when the yield stress of inner steel wall is less than the outer one, maximum load bearing capacity and ductility of the samples MSI240, MSI280, MSO360, and MSO400 are significantly higher than that of MSO240, MSO280, MSI360 and MSI400 samples. It means that in case that two kinds of steel with different yield stresses are available, if the steel with more yield stress to be used at outer steel wall, that would have a higher efficiency and a better performance from the viewpoint of ductility and load bearing capacity.

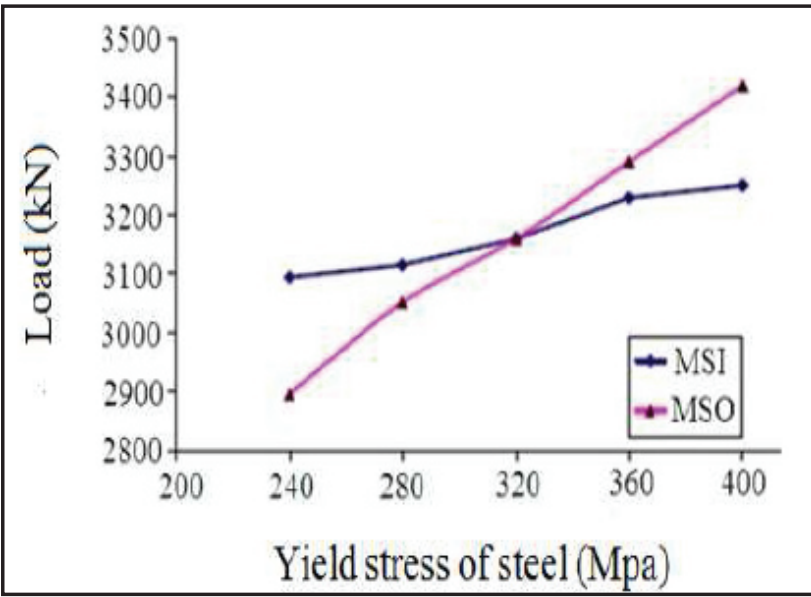

Figure 5: Effect of steel walls yield stress variations on the strength of CFDST columns

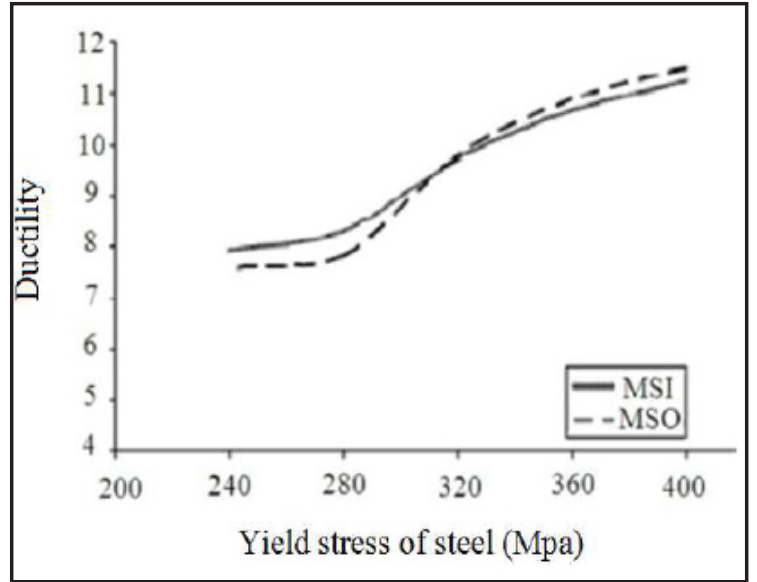

Figure 6: Effect of steel walls yield stress variations on the ductility of CFDST columns

Journal of Applied Engineering Science 15(2017)1,418
To assess the effect of concrete strength, five samples have been selected having various specified compressive strengths of CFDST samples. For this purpose, the yield stress and geometric specifications of the inner and outer steel wall for all specimens are the same and the strength of the filling concrete is variable.

For example, MSI240-C20 is the sample for which the concrete strength used in the samples is variable (20 to $60 \mathrm{MPa}$ ), supposing that the yield stress of outer and inner steel walls is fixed (320 MPa outer tube and $240 \mathrm{MPa}$ inner one). The material specifications of samples are presented in Table 4.

Figure 7 shows load increment percentage and concrete strength ratio responses of MSI240$\mathrm{C}^{*}$ samples. For comparison, MSI240-C20 has been selected as a benchmark specimen. It can be seen that load-carrying capacity of specimens increases as the strength of the filling concrete increases.

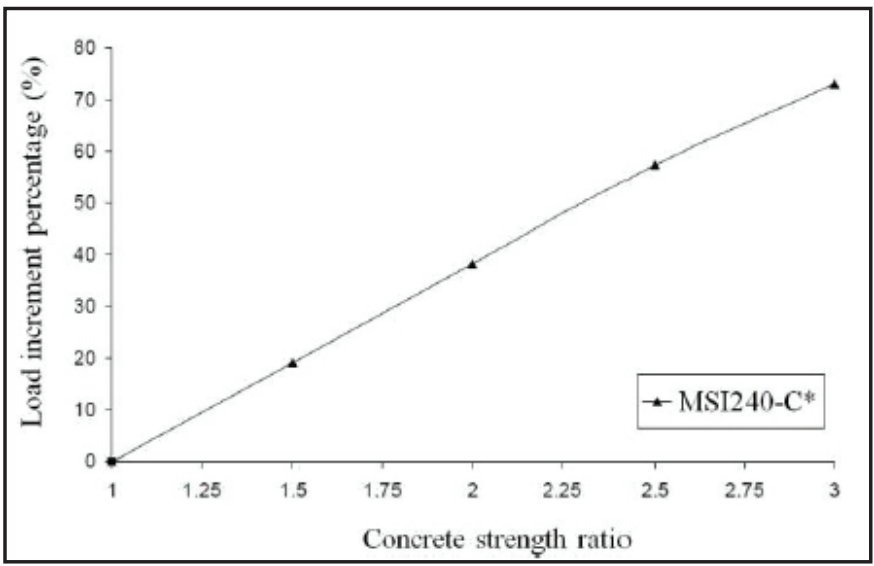

Figure 7: Effect of compressive strength of concrete on the strength of CFDST columns

Considering Figure 8 , it is observed that with the increase of concrete strength in specified range, ductility of samples increases, but for more increase of concrete strength, out of specified range, ductility of specimens, decreases. 
Table 4: The material specifications of component parts of CFDST columns

\begin{tabular}{|c|c|c||c|c|c|c||}
\hline \multicolumn{3}{|c|}{ Steel properties } & \multicolumn{2}{c|}{ Concrete properties } & \multirow{2}{*}{ Specimen } & \\
\hline \begin{tabular}{c}
\hline$E_{s}$ \\
$(\mathrm{MPa})$
\end{tabular} & $\begin{array}{c}\mathrm{f}_{\text {syi }} \\
(\mathrm{MPa})\end{array}$ & $\begin{array}{c}\mathrm{f}_{\text {syo }} \\
(\mathrm{MPa})\end{array}$ & $\begin{array}{c}\mathrm{E}_{\mathrm{c}} \\
(\mathrm{MPa})\end{array}$ & $\begin{array}{c}\mathrm{f}_{\mathrm{c}}{ }_{\mathrm{c}} \\
(\mathrm{MPa})\end{array}$ & $\mathrm{x}$ & \\
\hline 200,000 & 240 & 320 & 22400 & 20 & 0.495 & MSI 240-C20 \\
\hline 200,000 & 240 & 320 & 27400 & 30 & 0.495 & MSI 240-C30 \\
\hline 200,000 & 240 & 320 & 31600 & 40 & 0.495 & MSI 240-C40 \\
\hline 200,000 & 240 & 320 & 35400 & 50 & 0.495 & MSI 240-C50 \\
\hline 200,000 & 240 & 320 & 38700 & 60 & 0.495 & MSI 240-C60 \\
\hline
\end{tabular}

Therefore, this result clearly shows the considerable effects of concrete strength on the behavior of CFDST columns such that, for getting an appropriate behavior of CFDST columns, concrete strength of specimens would be suggested between 30 45MPa.

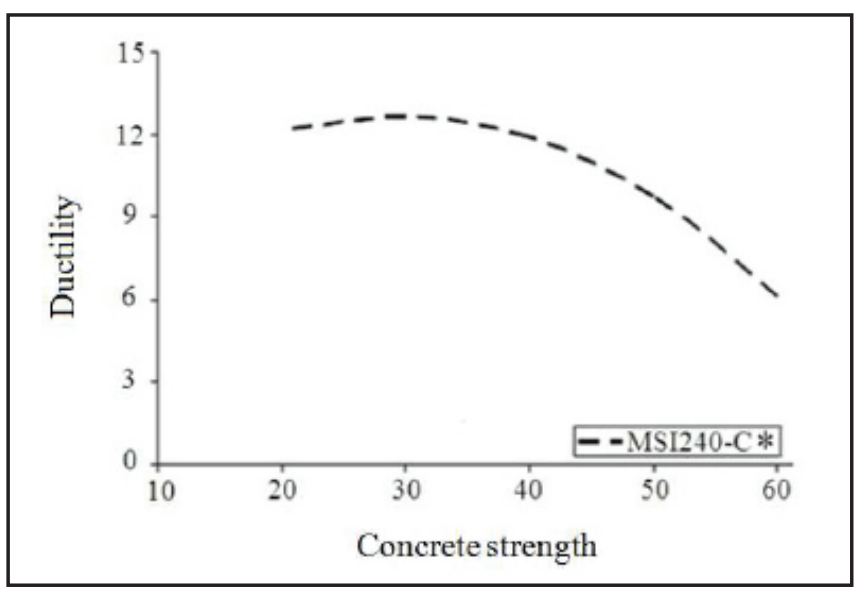

Figure 8: Effect of compressive strength of concrete on the ductility of CFDST columns

\section{EFFECT OF THICKNESS VARIATIONS OF STEEL WALL}

To assess the effect of steel wall's thickness variations, eight samples have been selected including the various thicknesses at outer and inner steel walls according to Tables 5 and 6 . For comparison purpose, ThicOut 4 and Thicln 2 has been selected as a benchmark specimen.

Figures 9 and 10 shows the effects of increment of steel wall area on the increment of strength and ductility of CFDST samples, respectively. It is defined that axial compression and ductility of CFDST samples increases as the thicknesses of the outer and inner steel walls increases, respectively. Considering the results in Figure 9, it is defined that with the increase of ratio of inner steel wall area at point 2.5 , load carrying capacity of specimens are increased about $5 \%$, while with the increase of ratio of outer steel wall at point 2.5 , load capacity of specimens are increased about $40 \%$.

Table 5: The specifications of specimens with various thicknesses at outer steel wall

\begin{tabular}{|c|c|c|c|c|c|}
\hline \multicolumn{4}{|c|}{ The thickness of outer steel wall is variable (Inner steel wall thickness is constant) } \\
\hline \multicolumn{2}{|c|}{ Sample } & \multicolumn{4}{|c|}{ ThicOut 4 8(Outer Thickness is variable) } \\
\hline $\begin{array}{c}\text { Wall } \\
\text { position }\end{array}$ & Diameter $(\mathrm{mm})$ & $\mathrm{t}_{1}(\mathrm{~mm})$ & $\mathrm{t}_{2}(\mathrm{~mm})$ & $\mathrm{t}_{3}(\mathrm{~mm})$ & $\mathrm{t}_{4}(\mathrm{~mm})$ \\
\hline OUT & 300 & 4 & 6 & 8 & 10 \\
\hline IN & 100 & \multicolumn{5}{|c|}{4 (Inner thickness is constant) } \\
\hline
\end{tabular}

Table 6: The specifications of specimens with various thicknesses at inner steel wall

\begin{tabular}{|c|c|c|c|c|c|}
\hline \multicolumn{4}{|c|}{ The thickness of outer steel wall is variable (Inner steel wall thickness is constant) } \\
\hline \multicolumn{2}{|c|}{ Sample } & \multicolumn{4}{c|}{ ThicOut 2 10(Outer Thickness is variable) } \\
\hline $\begin{array}{c}\text { Wall } \\
\text { position }\end{array}$ & Diameter (mm) & $\mathrm{t}_{1}(\mathrm{~mm})$ & $\mathrm{t}_{2}(\mathrm{~mm})$ & $\mathrm{t}_{3}(\mathrm{~mm})$ & $\mathrm{t}_{4}(\mathrm{~mm})$ \\
\hline OUT & 300 & 2 & 5 & 8 & 10 \\
\hline IN & 100 & \multicolumn{4}{|c|}{8 (Inner thickness is constant) } \\
\hline
\end{tabular}




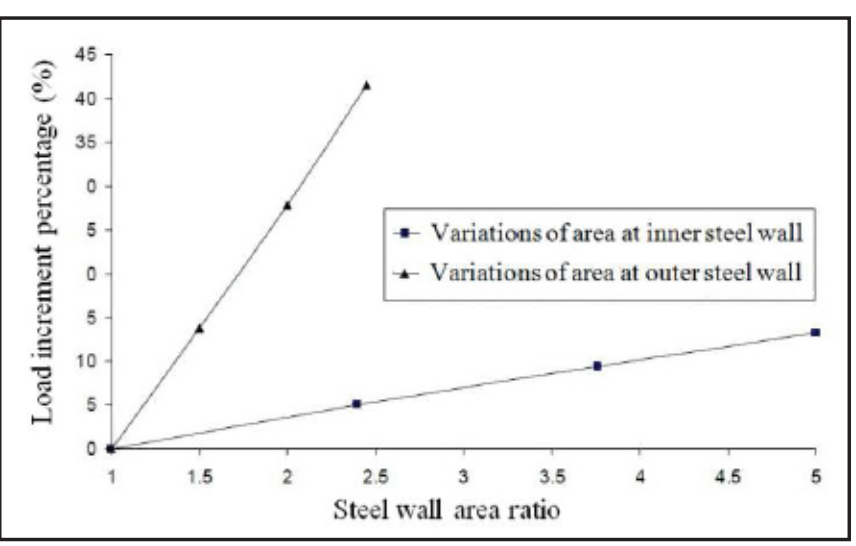

Figure 9: Effect of area of steel wall on the strength of CFDST columns

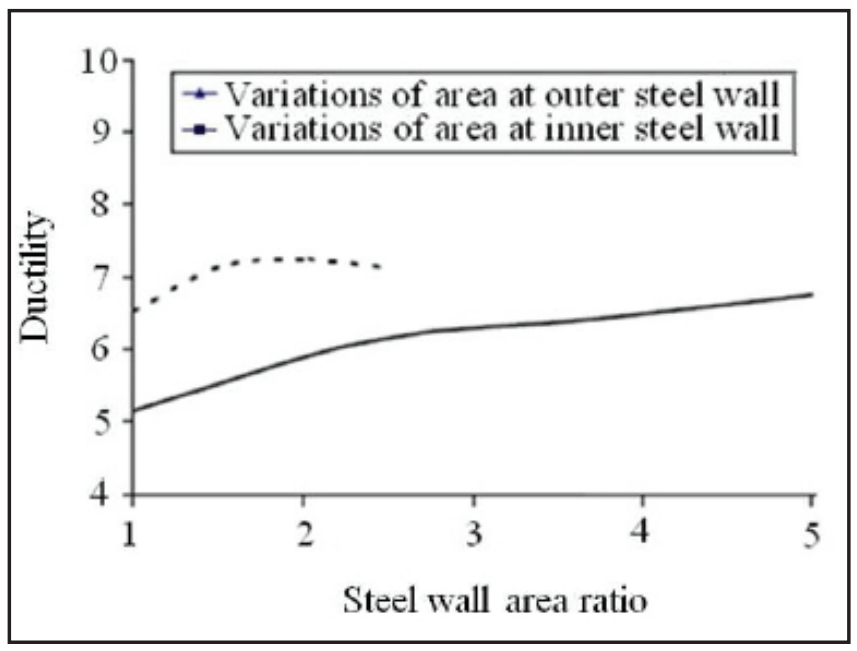

Figure 10: Effect of area of steel wall on the ductility of CFDST columns
That means the achieved load for the samples with outer steel wall thicknesses variations is considerably more than the variations of thicknesses in inner steel wall. The reason is that increment in the thicknesses of outer steel walls considerably affects on the concrete core confinement and that resulted in improvement of ductility and strength of the samples.

\section{EFFECT OF DIAMETER VARIATIONS OF STEEL WALL}

In order to assess the effect of diameter variations of steel wall, eight samples have been selected as shown in Tables 7 and 8 including the various thicknesses at outer and inner steel wall, respectively. It is noticeable that for the selection of these samples, D/t ratio of specimens have been considered the same amount for all samples $(\mathrm{D} / \mathrm{t}=2.5)$.

Figure 11 shows that by decrease of outer steel wall diameter (increase of $x$ factor, DimOut state), maximum load capacity of the samples efficiently decreases, while with the decrease of inner steel wall diameter (decrease of $x$ factor, DimIN state), degradation of strength has got inclined towards increasing slope with negligible increment of load capacity.

Table 7: The specifications of specimens with various diameters of outer steel wall

\begin{tabular}{|c||c|c|c|c|c|}
\hline \multicolumn{6}{|c|}{$\times$ variant and outer steel wall variations } \\
\hline & Sample & DimOut 200-8 & DimOut 250-10 & $\begin{array}{c}\text { DimOut 300- } \\
12\end{array}$ & DimOut350-14 \\
\hline \multirow{2}{*}{$\begin{array}{c}\text { Wall } \\
\text { position }\end{array}$} & OUT & $200 \times 8(\mathrm{~mm})$ & $250 \times 10(\mathrm{~mm})$ & $300 \times 12(\mathrm{~mm})$ & $350 \times 14(\mathrm{~mm})$ \\
\cline { 2 - 6 } & IN & & \multicolumn{4}{|c|}{$100 \times 5(\mathrm{~mm})$} & \\
\hline \multicolumn{7}{|c|}{$\mathrm{x}$} & 0.54 & 0.43 & 0.36 & 0.31 \\
\hline
\end{tabular}

Table 8: The specifications of specimens with various diameters of inner steel wall

\begin{tabular}{|c|c|c|c||c|c||}
\hline \multicolumn{6}{|c|}{ x variant and outer steel wall variations } \\
\hline & Sample & DimOut 100-4 & DimOut 150-6 & DimOut 200-8 & DimOut 250-10 \\
\hline \multirow{2}{*}{$\begin{array}{c}\text { Wall } \\
\text { position }\end{array}$} & OUT & $200 \times 8(\mathrm{~mm})$ & $250 \times 10(\mathrm{~mm})$ & $300 \times 12(\mathrm{~mm})$ & $350 \times 14(\mathrm{~mm})$ \\
\cline { 2 - 6 } & IN & \multicolumn{4}{|c|}{$100 \times 5(\mathrm{~mm})$} \\
\hline \hline
\end{tabular}




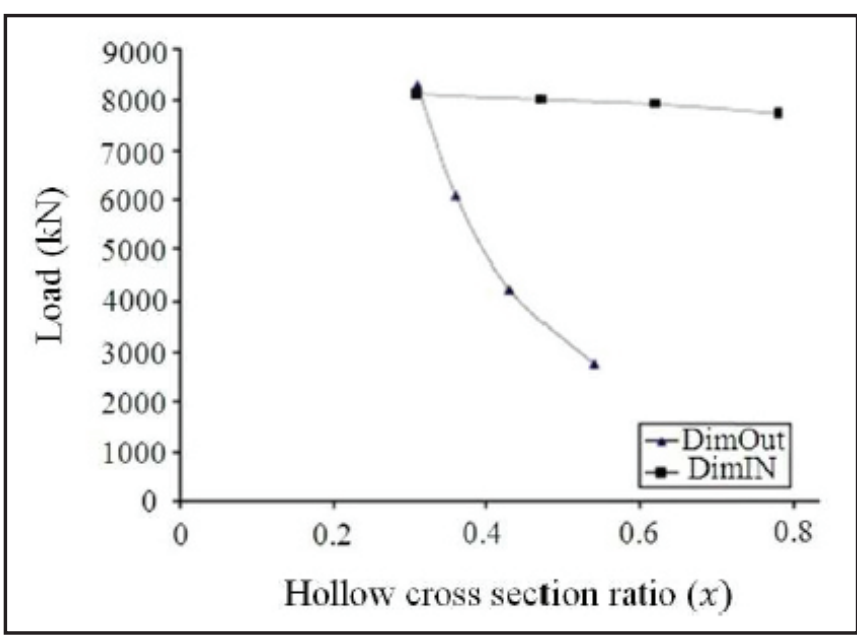

Figure 11: Effect of hollow cross section ratio on the strength of CFDST columns

Considering Figure 12, it is found that with the increase of $X$ factor in specified range, ductility of samples increases, but for more increase of $X$ factor, out of the specified range, ductility of specimens, decreases. So this result clearly shows the considerable effects of diameter variations on the behavior of CFDST columns such that, in order to increase the ductility and an appropriate behavior of CFDST columns, the increase of diameter of steel wall must be defined within a specified range.

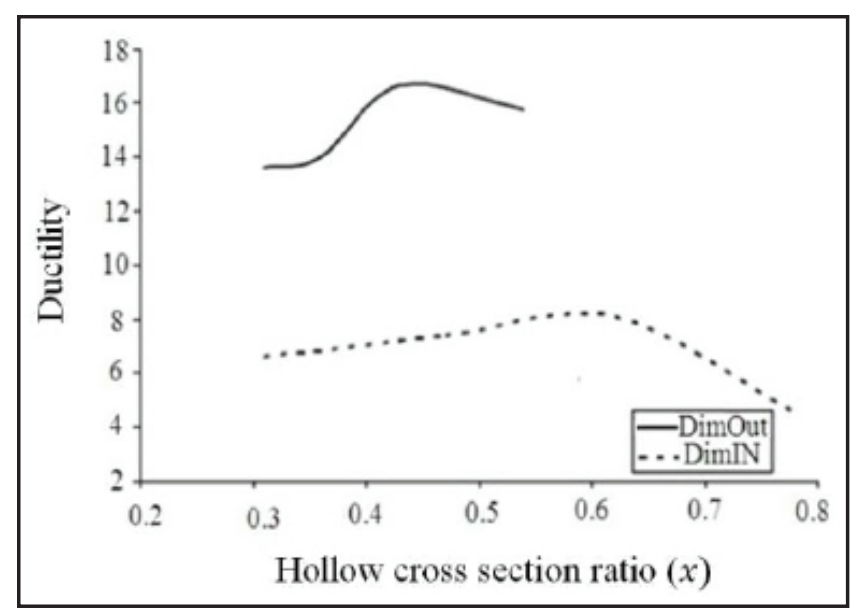

Figure 12: Effect of hollow cross section ratio on the ductility of CFDST columns

\section{COMPARISON OF EFFECTIVE PARAMETERS ON CFDST COLUMNS}

The quantitative comparison between some parameters such as yield stress variations of steel wall, compressive strength variations of concrete , thickness and diameter variations of steel wall for CFDST columns have been summarized in Table 9.
Considering Table 9 , with the increase of yield stress of steel wall, compressive strength of concrete, thickness, and diameter of steel wall, strength of specimens increases. In addition, with the increase of compressive strength of concrete and diameter of steel wall, ductility of specimens initially increases. But for more increase of those effective parameters out of an specified range, strength and ductility of specimens decreases.

\section{EFFECT OF LOAD APPLICATION TYPE}

In order to investigate the behavior of CFDST samples, under axial loading, three types of load application have been considered as shown in Figure 13. In the case of load application types (b) and (c), the axial load is applied only to the steel section and to the concrete core, respectively. However, in the case of load application type (a), the axial load is applied to the entire section. In each case, two rigid plates, located at the top and bottom of the columns, transfer load. Considering Figure 14, in the case of applying load to the entire section, The results show that the strength of samples in the case of load application type (a) is considerably higher than that of the load application types of (b) and (c). In the case of load application to the entire section, the samples exhibit appropriate strain-hardening characteristics on their post-yield behavior. In addition, steel walls show the highest ratio in terms of load carrying capacity of columns, not available in load application type of (c). Table 10 shows load application type effects into the load attraction ratio of component parts of CFDST columns. For comparison purpose, LFE state has been selected as a benchmark specimen. Considering the obtained results in Table 10, the amount of increase in the maximum load when load applied to the entire section is 6 percent and 25 percent more than (LFS) and (LFC) samples, respectively.

\section{CONCLUSIONS}

In the present study, some effective parameters into the buckling behavior of CFDST columnsunder axial loading have been investigated. The followings are conclusions:

1. To construct the composite CFDST columns, in case that two kinds of steel with different yield stresses are available, the steel with more yield stress is suggesting to be sued at outer steel wall to have a higher efficiency and a better performance from the viewpoint of ductility and load bearing capacity.

Journal of Applied Engineering Science 15(2017)1, 418 
Table 9: Comparison of effective parameters on CFDST columns

\begin{tabular}{|c|c|c|}
\hline Effective parameters & Strength & Ductility \\
\hline $\begin{array}{c}\text { Yield stress variations } \\
\text { ofsteel wall }\end{array}$ & Increases & Increases \\
\hline $\begin{array}{c}\text { Compressive strength } \\
\text { variations of concrete }\end{array}$ & Increases & $\begin{array}{c}\text { Initially increases } \\
\text { Then decreases }\end{array}$ \\
\hline $\begin{array}{c}\text { Thickness variations of } \\
\text { steel wall }\end{array}$ & Increases & Increases \\
\hline $\begin{array}{c}\text { Diameter variations of } \\
\text { steel wall }\end{array}$ & Increases & $\begin{array}{c}\text { Initially increases } \\
\text { Then decreases }\end{array}$ \\
\hline
\end{tabular}

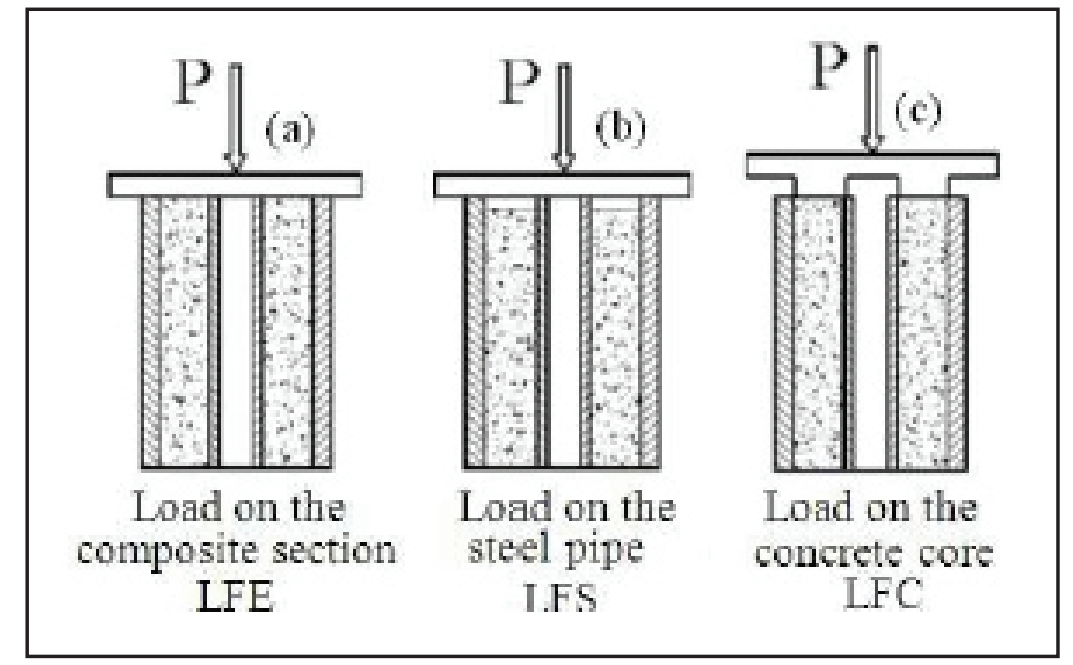

Figure 13: Three types of load application

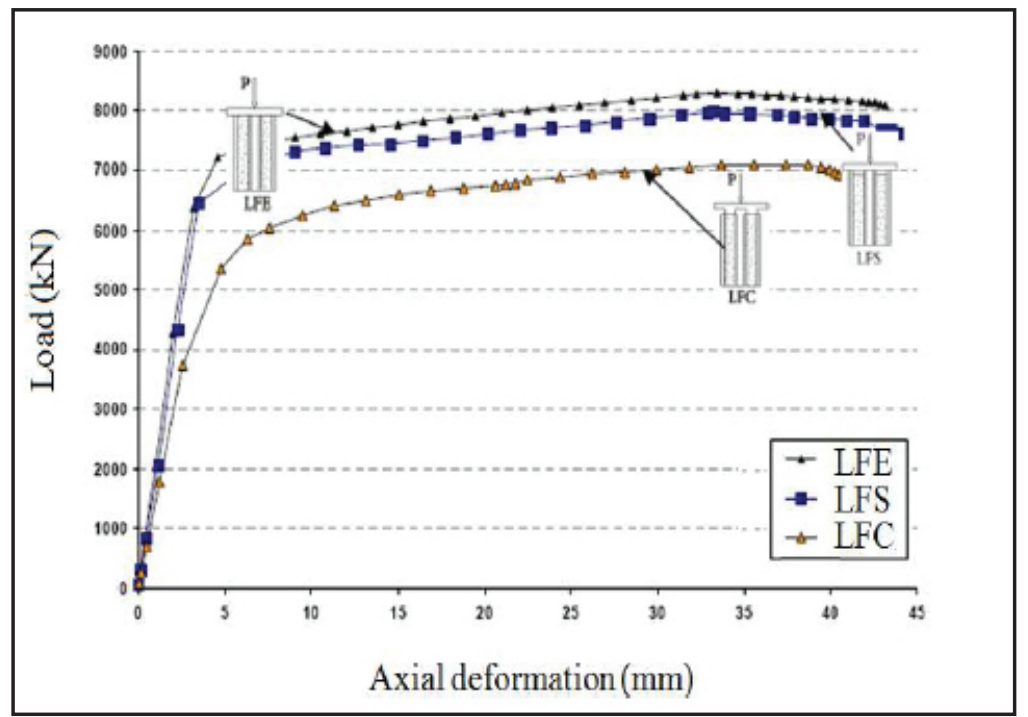

Figure 14: Effect of load application type on the strength of CFDST columns

2. The findings obviously illustrate the significant impact of concrete strength including the fact that the use of high strength filling concrete resulted in a reduction of CFDST's ductility. Therefore, for having a desirable behavior in CFDST columns, compressive strength of concrete should not exceed a specified range;
3. In order to have appropriate ductility of CFDST columns, the increase of diameter of steel wall should not be more than a specified range. The results show that the increase of thickness in outer steel wall gives behavior that is more appropriate rather than the increase of thicknesses in the inner steel wall. 
4. In the case of load application to the entire section, the columns exhibits appropriate strain-hardening characteristics on their post-yield behavior and a better performance from the viewpoint of ductility and load carrying capacity.

Table 10: Effect of load application type into the load attraction ratio of component parts

\begin{tabular}{|c|c|c|c|}
\hline \multicolumn{4}{|c|}{ Effect of loading state and the load attraction ration of component parts } \\
\hline State & $\begin{array}{c}\text { In comparison } \\
\text { to LFE state } \\
(\%)\end{array}$ & $\begin{array}{c}\text { Steel load } \\
\text { attraction ration } \\
(\%)\end{array}$ & $\begin{array}{c}\text { Concrete load } \\
\text { attraction ration } \\
(\%)\end{array}$ \\
\hline Load on the composite section (LFE) & 100 & 60.3 & 39.7 \\
\hline Load on the steel pipe(LFS) & 94.2 & 71.6 & 28.4 \\
\hline Load on the concrete core (LFC) & 75.8 & 43 & 57 \\
\hline
\end{tabular}

\section{REFERENCES}

1) Zhang, F., Wu, C., Zhao, X., Li, Z., Heidarpour, A., Wang, H., Numerical modeling of concrete-filled double-skin steel square tubular columns under blast loading, Journal of Performance of Constructed Facilities, 2015, 29(5), pp. 1 - 12.

2) Han L. H., Li Y. J., Liao F. Y., Concrete Filled Double Skin steel Tubular (CFDST) columns subjected to long-term sustained loading, Thin-walled structures, 2011, 49, pp. 15341543.

3) Li W., Ren Q. X., Han L. H., Behavior of tapered concrete-filled double skin steel tubular stub columns, Thin-walled structures, 2012, 57, pp. 37-48.

4) Han, L. H., Tao, Z., Huang, H., Zhao, X. L., Concrete-filled double skin (SHS outer and CHS inner) steel tubular beam-columns. Thinwalled structures, 2004, 42(9), pp. 1329-1355.

5) Tao Z., Han L. H., Zhao X. L., Behavior of concrete filled double skin (CHS inner and CHS outer) steel tubular stub columns and beam-columns, Journal of Constructional Steel Research, 2004, 60, pp. 1129-1158.

6) Uenaka, K., Kitoh, H., Sonoda, K., Concrete filled double skin circular stub columns under compression, Thin-walled structures, 2010, 48(1), pp. 19-24

7) Fan, J., Baig, M., Nie, J., Test and analysis on double-skin concrete filled tubular columns. Tubular Structures XII: Proceedings of Tubular Structures XII, Shanghai, China, 2008.

8) Han T. H., Stallings J. M., Kang Y. J., Nonlinear concrete model for double-skinned composite tubular columns, Construction and Building Materials, 2010, 24 (12): 25422553.
9) Han Lin Hai, Huang Hong, Zhao Xiao-Ling, Analytical behaviour of concrete-filled double skin steel tubular (CFDST) beam-columns under cyclic loading, Thin-Walled Structures, 2009, 47(6): 668-680.

10) Shah K. D., Vakil M. D., Patel M. N., Parametric study of concrete filled steel tube column, International Journal of Engineering Development and Research, 2014, 2(2), pp. 1678-1682.

11) Gupta P. K., Sarda S. M., Kumar M. S., Experimental and computational study of concrete filled steel tubular columns under axial loads, Journal of Constructional Steel Research, 2007, 63, pp. 182-193.

12) ANSYS R 10.0, Academic, Structural analysis guide, 2005.

13) Schneider S. P., Axially loaded concrete filled steel tubes, ASCE Journal of Structural Engineering, 1998, 124(10), pp. 1125-1138.

14) Mursi, M., Uy, B., Strength of concrete filled steel box columns incorporating interaction buckling, Journal of Structural Engineering, 2003, 129(5), pp. 626-639.

15) $\mathrm{ACl} 318$ "Building code requirements for reinfo rced concrete", American Concrete Institute, Detroit, Michigan, 1995.

16) AISC/LRFD, Manual of steel construction, Load and Resistance Factor Design, American Institute of Steel Construction, Part 4, Composite Columns, 2003.

Paper sent to revision: 21.11.2016.

Paper ready for publication: 16.01.2017. 